\title{
Promosi dengan Minat Beli Konsumen Produk Indocoverban Studi pada Konsumen Indocoverban
}

\author{
Surya Menggala Putra ${ }^{1}$, Mustopa ${ }^{2}$ \\ ${ }^{1,2}$ Sekolah Tinggi Ilmu Komunikasi Indonesisa Maju \\ Email correspondent: gilangfrihady@gmail.com
}

\begin{abstract}
Abstrak
Untuk dapat meningkatan penjualan perlu dilakukan survey bagaimana menilai produk Indocoverban dari penilaian konsumen. Penelitian bertujuan untuk mengetahui hubungan kualitas produk, harga, citra merek dan promosi terhadap minat beli konsumen produk Indocoverban Jakarta Selatan tahun 2018. Tujuan penelitian ini untuk mengetahui hubungan antara kualitas produk, harga, citra merek dan promosi terhadap minat beli konsumen produk Indocoverban jakarta selatan tahun 2018. Penelitian ini merupakan jenis kuantitatif yang bersifat analitik. Desain penelitian yang digunakan ialah studi cross sectional. Populasi yang menjadi objek penelitian ini ialah kosumen pengguna produk Indocoverban di Jakarta Selatan pada tahun 2018 sebanyak 280 orang. Sampel dalam penelitian ini berdasarkan perhitungan rumus Slovin menjadi 74 sampel dengan teknik pengambilan sampel yaitu Sampling aksidental. Berdasarkan hasil penelitian ada hubungan variabel kualitas produk terhadap minat beli konsumen produk dengan nilai $\mathrm{P}=0,000$. Ada hubungan variabel harga produk terhadap minat beli konsumen produk dengan nilai $\mathrm{P}=0,000$. Ada hubungan variabel citra merek produk terhadap minat beli konsumen produk Indocoverban di Jakarta Selatan dengan nilai $\mathrm{P}=0,000$. Ada hubungan variabel promosi produk terhadap minat beli konsumen produk dengan nilai $\mathrm{P}=0,000$. Kesimpulannya ada hubungan antara kualitas produk, harga, citra merek dan promosi terhadap minat beli konsumen produk Indocoverban jakarta selatan tahun 2018.
\end{abstract}

Kata Kunci: harga, kualitas, merek, minat, promosi.

\begin{abstract}
To increase sales, a survey on how to value Indocoverban products from consumer ratings is needed. The study aims to determine the relationship of product quality, price, brand image, and promotion of consumer buying interest of South Jakarta Indocoverban products in 2018. The purpose of this study was to determine the relationship between product quality, price, brand image, and promotion of consumer buying interest of South Jakarta Indocoverban products in 2018. This research is a quantitative type that is analytic. The research design used was a cross-sectional study. The population that is the object of this research is the consumer users of Indocoverban products in South Jakarta in 2018 as many as 280 people. The sample in this study is based on the calculation of the Slovin formula into 74 samples with a sampling technique that is accidental sampling. Based on the results of the study there is a relationship between product quality variables on consumer product buying interest with a value of $P=0,000$. There is a variable relationship between product price and consumer purchase interest of the product with a value of $P=0,000$. There is a relationship between the product brand image variable and consumer purchase interest of Indocoverban products in South Jakarta with a value of $P=0,000$. There is a relationship between product promotion variables and consumer buying interest in the product with a value of $P=$ 0,000 . The conclusion is that there is a relationship between product quality, price, brand image, and promotion of consumer buying interest of South Jakarta Indocoverban products in 2018.
\end{abstract}

Keywords: brand, interest, promotion, price, quality. 


\section{Pendahuluan}

Dalam sejarah kehidupan manusia tidak pernah luput dengan yang namanya perkembangan dan perubahan. hal itu di tuntut supaya manusia bisa bertahan hidup dan bisa menyesuaikan dengan perubahan zaman yang semakin canggih. Salah satu aspek kehidupan yang selalu berkembang yaitu teknologi. Teknologi selalu diartikan sebagai segala sesuatu yang menyangkut berbagai cara ataupun teknik yang memproduksi, memelihara dan memakai segala peralatannya serta perlengkapannya untuk dapat bertahan hidup. Salah satu perkembangan teknologi yang paling dirasakan ialah transportasi. Pada mulanya manusia hanya menggandalkan tenaga binatang sebagai alat transportasi untuk mencapai tujuan. Kemajuan teknologi membuat moda transportasi di Indonesia mulai berubah dari alat gerobak yang beroda sampai dengan menggunakan mesin-mesin bermotor. ${ }^{1}$

Istilah industri transportasi selalu tidak lepas dari kendaraan bermotor salah satunya ialah mobil. Perolehan data bersumber dari Mabes Polri diketahui bahwa jumlah banyaknya kendaraan yang terdaftar per tanggal 1 Januari di Indonesia 2018 mencapai 111.571.239 unit kendaraaan. Angka itu termasuk jumlah kendaraan sepeda motor yang telah berkontribusi terbesar yaitu sebanyak $82 \%$ atau 91.085 .532 unit sepeda motor. Menyusul Mobil Pribadi dengan kontribusi 12\% atau sebanyak 13.253.143 unit mobil. Sisanya kontribusi dari Mobil Bus, Mobil Barang, dan Kendaraan Khusus. ${ }^{2}$

Banyaknya kepemilikan kendaraan jenis roda empat yang khususnya kendaraan pribadi di negara Indonesia pada tahun ke tahun terus semakin mengalami peningkatan jumlah kendaraannya. Pemilik mobil sebagian besar merasakan bangga apabila kendaraannya memiliki tampilan yang trendy, gaya, unik, serta tampil beda daripada mobil yang lain. Dengan banyaknya jumlah kendaraan saat ini terutama mobil membuat banyak perusahaan berbondong-bondong mencari peluang di bidang otomotif salah satunya dengan membuka usaha aksesoris mobil. Hal inilah yang dimanfaatkan oleh Indocoverban sebuah usaha penyediaan aksesoris mobil yang terletak di Jakarta Selatan. owner dari Indocoverban, pada awalnya beliau membuka usaha penyedia sarung jok motor. Namun kala itu, banyak konsumen yang datang untuk meminta bantuannya untuk membuatkan sarung ban mobil. ${ }^{3}$

Produk merupakan semua hal yang bisa ditawarkan kepada pasar untuk menarik perhatian, akusisi, penggunaan atau konsumsi yang bisa memuaskan daripada keinginan atau kebutuhan konsumen. Jadi disini yang dimaksud ialah perusahaan dengan produk paling baik yang dapat tumbuh dengan pesat, dan dalam jangka panjang perusahan tersebut akan lebih berhasil dari perusahaan yang lain. $^{4}$

Pemahaman perusahaan akan minat beli konsumen berawal dari kualitas produk, selanjutnya disesuaikan dengan harga, citra merek dan promosi. Pemikiran yang berorientasi pada pasar dan konsumen merupakan kebutuhan yang tidak dapat dielakkan lagi di era persaingan bisnis yang hypercompetition. Pada zaman ini dapat diyakini sebagai zaman dengan ketidakpastian yang dibarengi pada munculnya fase pertumbuhan yang tidak dapat menentu. Salah satu penyebabnya ialah tingginya tingkat persaingan di dunia baik bisnis lokal maupun global. Tingkat persaingan yang ketat antara perusahaan menyebabkan perusahaan harus benar-benar memikirkan strategi yang tepat dalam ialah sesuatu yang diperoleh dari proses belajar dan proses pemikiran yang yang membentuk suatu persepsi. Minat beli ini menciptakan suatu motivasi yang terus terekam dalam benaknya dan menjadi suatu keinginan yang sangat kuat yang pada akhirnya ketika seorang konsumen harus memenuhi kebutuhannya akan mengaktualisasikan apa yang ada didalam benaknya itu. ${ }^{5}$

Kualitas produk ialah kemampuan sebuah produk dalam memperagakan fungsinya, hal itu termasuk keseluruhan durabilitas, reliabilitas, ketepatan, kemudahan pengoperasian dan reparasi produk juga atribut produk lainnya. Dengan kualitas produk dan pelayanan yang baik maka dengan sendirinya konsumen akan merasa nyaman dam mempengaruhi minat beli. ${ }^{6}$

Tujuan dari penetapan suatu harga ialah untuk mencapai target perusahaan, mendapatkan laba dari penjualan, meningkatkan serta mengembangkan produksi produk, serta meluaskan target 
pemasaran Harga memiliki peranan yang sangat penting dalam mempengaruhi keputusan konsumen dalam membeli produk, sehingga sangat menentukan keberhasilan pemasaran suatu produk. Kesuksesan dalam penetapan harga merupakan elemen kunci dalam bauran pemasaran. Harga merupakan unsur bauran pemasaran yang bersifat fleksibel, artinya dapat diubah dengan cepat. Harga merupakan satu- satunya elemen dalam bauran pemasaran yang menghasilkan pendapatan bagi perusahaan, oleh sebab itu harga dapat dikatakan mendatangkan laba bagi perusahaan. Harga dapat menjadi alat yang menjadi kompetitif dalam bersaing. Harga merupakan sesuatu yang diserahkan dalam pertukaran untuk mendapatkan suatu barang atau jasa. ${ }^{7}$

Indocoverban memberikan kepada konsumen harga yang tertera pada label dan cenderung lebih murah dari toko-toko lain. Harga berpengaruh positif dan signifikan terhadap keputusan pembelian. ${ }^{8}$

Citra merek merupakan representasi dari keseluruhan persepsi terhadap merek dan dibentuk dari informasi dan pengetahuan terhadap merek itu. Citra terhadap merek berhubungan dengan sikap yang berupa keyakinan dan preferensi terhadap suatu merek. Konsumen yang memiliki citra yang positif terhadap suatu merek akan lebih memungkinkan untuk melakukan pembelian. ${ }^{9}$

Pemberian merek yang unik dan kreatif sehingga membangun citra merek atau brand image yang positif juga merupakan salah satu strategi untuk menarik minat beli konsumen. Citra merek ialah seperangkat asosiasi unik yang ingin diciptakan atau dipelihara oleh pemasar. ${ }^{10}$

Brand image atau brand description ialah deskripsi tentang asosiasi dan keyakinan konsumen terhadap merek tertentu. Citra merek menjadi hal yang sangat penting yang harus diperhatikan oleh perusahaan selaku pelaku pasar, karena melalui citra merek yang baik akan menimbulkan nilai-nilai emosional pada diri konsumen. ${ }^{11}$

Promosi ialah arus informasi atau persuasi satu arah yang dibuat untuk mengarahkan seseorang atau organisasi kepada tindakan yang menciptakan pertukaran dalam pemasaran. Faktor promosi dapat mempengaruhi perilaku konsumen dalam melakukan keputusan membeli. Dengan promosi menyebabkan orang yang sebelumnya tidak tertarik untuk membeli suatu produk akan menjadi tertarik dan mencoba produk sehingga konsumen melakukan pembelian. Promosi merupakan faktor penting dalam mewujudkan tujuan penjualan suatu perusahaan Agar konsumen bersedia menjadi langganan, mereka terlebih dahulu harus dapat mencoba atau meneliti barang-barang yang diproduksi oleh perusahaan, akan tetapi mereka tidak akan melakukan hal tersebut jika kurang yakin terhadap barang itu. Disinilah perlunya mengadakan promosi yang terarah, karena diharapkan dapat memberikan pengaruh positif terhadap meningkatnya penjualan. ${ }^{12}$

Indocoverban merupakan perusahaan perorangan sebagai owner Indocoverban, beroperasi secara penuh sejak tahun 2016 menyediakan jasa dan produk berbasis aksesoris kendaraan. Indocoverban membuka workshop di Jl. Raya Tanjung Barat No. 18 RT/RW: 09/07 Pasar Minggu, Jakarta Selatan. Indocoverban menggunakan system jual beli online melalui sosial media dan memanfaatkan akun-akun marketplace yang dinilai lebih efektif dan menjangkau konsumen secara luas. Selain berjualan melalui social media Indocoverban juga rutin mengikuti acara-acara pameran automotive sebagai media promosi. Beberapa kali Indocoverban mendapatkan penghargaan pada ajang pameran automotive sebagai brand aksesoris mobil pendatang baru favorite yang diselenggarakan oleh komunitas pecinta modifikasi mobil.

Tujuan dari penelitian ini ialah untuk mengetahui hubungan antara kualitas produk, harga, citra merek dan promosi terhadap minat beli konsumen produk Indocoverban jakarta selatan tahun 2018.

\section{Metode}

Penelitian ini merupakan jenis kuantitatif yang bersifat analitik. Suatu peneliti yang bertujuan untuk menganalisis atau penelitian hubungan antara kualitas produk, harga, citra merek dan promosi terhadap minat beli konsumen produk Indocoverban (Studi Pada Konsumen Indocoverban di Jakarta 
Selatan Tahun 2018). Penelitian jenis kuantitatif digunakan karena peneliti mengambil sampel dari satu populasi dengan menggunakan kuesioner sebagai alat ukur pengumpulan data. ${ }^{13}$

Desain penelitian yang digunakan ialah studi cross sectional atau potong lintang. Desain studi cross sectional digunakan karena dapat memberikan informasi atau gambaran analisis dalam satu waktu yang bersamaan atau dengan kata lain yaitu suatu penelitian untuk mempelajari dinamika kolerasi antara faktor- faktor risiko dengan efek, dengan cara pendekatan, obsevasi atau pengumpulan data sekaligus pada suatu saat (point time approach). Artinya, tiap subjek penelitian hanya diobservasi sekali saja dan pengukuran dilakukan terhadap status karakter atau variabel subjek pada saat pemeriksaan. Hal ini tidak berarti bahwa semua subjek penelitian diamati pada waktu yang sama. Desain ini dapat mengetahui dengan jelas mana yang jadi pemajan dan outcome, serta jelas kaitannya hubungan sebab akibatnya. ${ }^{14}$ Prosedur pengumpulan data ini ialah dengan membagikan kuisioner kepada responen mengenai minat beli konsumen Indocoverban. Penelitian ini mencoba menggali bagaimana dan mengapa fenomena variabel independent (kualitas produk, harga produk, citra merek, dan promosi) dan variabel dependen (minat beli) di Indocoverban Jakarta Selatan dengan tujuan untuk mengetahui ada tidaknya hubungan antara variabel-variabel tersebut.

Penelitian ini dilakukan di Indocoverban yang beralamatkan di Jl. raya Tanjung Barat No. 18 RT/RW: 09/07 pasar Minggu Jakarta Selatan pada bulan Oktober - Desember 2018.

Populasi ialah keseluruhan objek atau individu dalam ruang lingkup yang hendak diteliti atau disebut sebagai kumpulan objek penelitian. ${ }^{15}$ Populasi yang akan menjadi objek penelitian ini ialah kosumen pengguna produk Indocoverban di Jakarta Selatan pada tahun 2018 sebanyak 280 orang.

Sampel merupakan objek yang diteliti dan dianggap mewakili seluruh populasi. Sampel ialah bagian dari jumlah dan karakteristik yang dimiliki oleh populasi tersebut. Pertama ditentukan berapa batas toleransi kesalahan. Batas toleransi kesalahan ini dinyatakan dengan presentase. ${ }^{16}$ Jumlah sampel penelitian ini sebanyak 280 orang.

Teknik sampling ialah cara untuk menentukan sample yang jumlahnya sesuai dengan ukuran sample yang akan dijadikan sumber data sebenarnya, dengan memperhatikan sifat-sifat dan penyebaran populasi agar diperoleh sample yang representative. ${ }^{17}$ Peneliti menggunakan Teknik pengambilan Non- probability Sampling yaitu dengan Sampling aksidental ialah teknik penentuan sampel berdasarkan kebetulan siapa saja yang bertemu dengan peneliti dapat digunakan sebagai sampel, bila dipandang orang yang kebetulan ditemui itu cocoksebagai sumber data.

Instrumen yang digunakan dalam penelitian ini ialah kuisioner yang berisi pertanyaan mengenai variabel indpenden (kualitas produk, harga produk, citra merek, dan promosi) dan variabel dependen (minat beli). Validitas ialah suatu ukuran yang menunjukkan tingkat kesahihan tingkat instrument penelitian. Suatu instrument penelitian yang valid mempunyai validitas yang tinggi, sebaliknya instrument yang kurang valid berarti memiliki validitas yang rendah. ${ }^{18}$ Alat ukur disebut reliabel bila alat ukur tersebut secara konsisten memberikan hasil atau jawaban yang sama terhadap gejala yang sama walau digunakan berulang kali. Reabilitas mengandung arti bahwa alat ukur tersebut stabil (tidak berubah- ubah), dapat diandalkan (dependable) dan tetap (consistent). ${ }^{19}$

Analisis univariat yaitu analisa dilakukan terhadap tiap variabel dari hasil penelitian, digunakan untuk mendapatkan distribusi frekuensi dari variabel independen dan dependen sehingga dapat diketahui jumlah dan persentasi dari masing-masing variabel.

Analisis bivariat yaitu analisa yang dilakukan melihat kemaknaan hubungan antara variabel independen dengan variabel dependen, menggunakan analisis hubungan kategori dengan kategori yaitu uji hipotesis penelitian dengan Uji Chi Square $\left(\mathrm{X}^{2}\right)$. 
Hasil

Tabel 1. Distribusi Frekuensi Responden Berdasarkan Minat Beli, Kualitas Produk, Citra Merek, Promosi Konsumen Produk Indocoverban di Jakarta Selatan

\begin{tabular}{lcc}
\hline \multicolumn{1}{c}{ Variabel } & Frekuensi & Persentase \% \\
\hline Minat Beli & & \\
Berminat & 51 & 68,9 \\
Kurang & 23 & 31,1 \\
Kualitas Produk & 52 & 70,3 \\
Berminat & 22 & 29,7 \\
Kurang & & 60,8 \\
Harga Produk & 45 & 39,2 \\
Berminat & 29 & 73,0 \\
Kurang & & 27,0 \\
Citra Merek Produk & 54 & 60,8 \\
Berminat & 20 & 39,2 \\
Kurang & & \\
Promosi Produk & 45 & \\
Berminat & 29 & \\
Kurang & &
\end{tabular}

Sumber: Data Primer 2018

Tabel 2. Promosi Dengan Minat Beli Konsumen Produk Indocoverban Studi Pada Konsumen Indocoverban Di Jakarta Selatan

\begin{tabular}{|c|c|c|c|c|c|c|c|c|}
\hline \multirow[b]{2}{*}{ Variabel } & \multicolumn{4}{|c|}{ Minat Beli } & \multirow{2}{*}{\multicolumn{2}{|c|}{ Total }} & \multirow{2}{*}{$\begin{array}{c}\text { P- } \\
\text { Value }\end{array}$} & \multirow{2}{*}{ OR } \\
\hline & & aik & & g Baik & & & & \\
\hline \multicolumn{9}{|l|}{ Kualitas Produk } \\
\hline Berminat & 44 & 84,6 & 8 & 15,4 & 52 & 100 & \multirow{3}{*}{0.000} & \multirow{3}{*}{11,786} \\
\hline Kurang & 7 & 31,8 & 15 & 68,2 & 22 & 100 & & \\
\hline Jumlah & 51 & 68,9 & 23 & 31,1 & 74 & 100 & & \\
\hline \multicolumn{9}{|l|}{ Harga Produk } \\
\hline Berminat & 42 & 93,3 & 3 & 6,7 & 45 & 100 & \multirow{3}{*}{0.000} & \multirow{3}{*}{31,111} \\
\hline Kurang & 9 & 31 & 20 & 69 & 29 & 100 & & \\
\hline Jumlah & 51 & 68,9 & 23 & 31,1 & 74 & 100 & & \\
\hline \multicolumn{9}{|c|}{ Citra Merek Produk } \\
\hline Berminat & 46 & 85,2 & 8 & 14,8 & 54 & 100 & \multirow{3}{*}{0.000} & \multirow{3}{*}{17,250} \\
\hline Kurang & 5 & 25 & 15 & 75 & 20 & 100 & & \\
\hline Jumlah & 51 & 68,9 & 23 & 31,1 & 74 & 100 & & \\
\hline \multicolumn{9}{|l|}{ Promosi Produk } \\
\hline Berminat & 41 & 91,1 & 4 & 8,9 & 45 & 100 & \multirow{3}{*}{0.000} & \multirow{3}{*}{19,475} \\
\hline Kurang & 10 & 34,5 & 19 & 65,5 & 29 & 100 & & \\
\hline Jumlah & 51 & 68,9 & 23 & 31,1 & 74 & 100 & & \\
\hline
\end{tabular}

Sumber: Data Primer 2018

Berdasarkan tabel 1 menunjukan bahwa distribusi frekuensi responden berdasarkan minat beli konsumen produk Indocoverban di Jakarta Selatan menyatakan bahwa frekuensi terbesar ialah minat beli baik sebanyak 51 responden atau 68,9\%. Menunjukan bahwa distribusi frekuensi responden berdasarkan kualitas produk Indocoverban di Jakarta Selatan menyatakan bahwa frekuensi terbesar ialah 
kualitas produk baik sebanyak 52 responden atau 70,3\%. Menunjukan bahwa distribusi frekuensi responden berdasarkan harga produk Indocoverban di Jakarta Selatan menyatakan bahwa frekuensi terbesar ialah harga produk baik sebanyak 45 responden atau 60,8\%. Menunjukan bahwa distribusi frekuensi responden berdasarkan citra merek Indocoverban di Jakarta Selatan menyatakan bahwa frekuensi terbesar ialah citra merek baik sebanyak 54 responden atau $73 \%$. Menunjukan bahwa distribusi frekuensi responden berdasarkan promosi Indocoverban di Jakarta Selatan menyatakan bahwa frekuensi terbesar ialah promosi baik sebanyak 45 responden atau $60,8 \%$.

Berdasarkan tabel 2 di dapatkan hasil analisa hubungan variabel kualitas produk terhadap minat beli konsumen produk Indocoverban di Jakarta Selatan bahwa sebanyak 44 responden $(84,6 \%)$ ialah kualitas produk baik dengan minat beli konsumen baik sedangkan sebanyak 15 responden $(68,2 \%)$ ialah kualitas produk kurang baik dengan minat beli konsumen kurang baik. Hasil uji statistik di dapat nilai $\mathrm{P}$ $=0,000$ berarti $\mathrm{P}<0,05$, sehingga dapat di simpulkan ada hubungan variabel kualitas produk terhadap minat beli konsumen produk Indocoverban di Jakarta Selatan. Dari nilai OR 11,786 dapat di simpulkan bahwa responden yang kualitas produk baik berpeluang 11,7 kali mengalami minat beli baik dibandingkan kualitas produk kurang baik. Didapatkan hasil analisa hubungan variabel harga produk terhadap minat beli konsumen produk Indocoverban di Jakarta Selatan bahwa sebanyak 42 responden $(93,3 \%)$ ialah harga produk baik dengan minat beli konsumen baik sedangkan sebanyak 20 responden (69\%) ialah harga produk kurang baik dengan minat beli konsumen kurang baik. Hasil uji statistik di dapat nilai $\mathrm{P}=0,000$ berarti $\mathrm{P}<0,05$, sehingga dapat di simpulkan ada hubungan variabel harga produk terhadap minat beli konsumen produk Indocoverban di Jakarta Selatan. Dari nilai OR 21,111 dapat di simpulkan bahwa responden yang harga produk baik berpeluang 21,1 kali mengalami minat beli baik dibandingkan harga produk kurang baik. Didapatkan hasil analisa hubungan variabel citra merek produk terhadap minat beli konsumen produk Indocoverban di Jakarta Selatan bahwa sebanyak 46 responden $(85,2 \%)$ ialah citra merek produk baik dengan minat beli konsumen baik sedangkan sebanyak 15 responden (75\%) ialah citra merek produk kurang baik dengan minat beli konsumen kurang baik. Hasil uji statistik di dapat nilai $\mathrm{P}=0,000$ berarti $\mathrm{P}<0,05$, sehingga dapat di simpulkan ada hubungan variabel citra merek produk terhadap minat beli konsumen produk Indocoverban di Jakarta Selatan. Dari nilai OR 17,250 dapat di simpulkan bahwa responden yang citra merek produk baik berpeluang 17,2 kali mengalami minat beli baik dibandingkan citra merek produk kurang baik. Didapatkan hasil analisa hubungan variabel promosi produk terhadap minat beli konsumen produk Indocoverban di Jakarta Selatan bahwa sebanyak 41responden $(91,1 \%)$ ialah promosi produk baik dengan minat beli konsumen baik sedangkan sebanyak 19 responden $(65,5 \%)$ ialah promosi produk kurang baik dengan minat beli konsumen kurang baik. Hasil uji statistik di dapat nilai $\mathrm{P}=0,000$ berarti $\mathrm{P}<0,05$, sehingga dapat di simpulkan ada hubungan variabel promosi produk terhadap minat beli konsumen produk Indocoverban di Jakarta Selatan. Dari nilai OR 19,475 dapat di simpulkan bahwa responden yang promosi produk baik berpeluang 19,4 kali mengalami minat beli baik dibandingkan promosi produk kurang baik.

\section{Pembahasan \\ Hubungan Kualitas Produk Dengan Minat Beli Konsumen Indocoverban di Jakarta Selatan}

Berdasarkan dari hasil bivariat, Hasil uji statistik diperoleh diperoleh nilai $\mathrm{p}$ value $=0,000$ dengan $\mathrm{p}$ value $<0,05$ sehingga dapat diartikan bahwa ada hubungan yang bermakna antara kualitas produk Indocoverban dengan minat beli konsumen di Jakarta Selatan tahun 2018. Hasil uji analisis menunjukan nilai Odds Ratio $(\mathrm{OR})=11,786$, artinya bahwa responden dengan kualitas produk baik berpeluang 11,7 kali mengalami minat beli baik dibandingkan kualitas produk kurang baik.

Konsumen yang telah merasa puas atas produk Indocoverban yang digunakannya akan cenderung melakukan pembelian ulang produk yang sama karena kualitasnya. Jika kualitasnya baik serta didukung oleh periklanan yang intensif pasti loyalitas pada merek produk tersebut akan dimiliki 
karena keduanya merupakan faktor kunci untuk menciptakan kepuasan konsumen pula bahkan beberapa penelitian menunjukkan bahwa konsumen akan memiliki minat beli terhadap merek berkualitas ketika produk-produk tersebut ditawarkan dengan harga yang wajar. ${ }^{20}$

Kualitas produk Indocoverban dapat diperoleh dengan cara membandingkan antara harapan konsumen dengan penilaian mereka terhadap kinerja yang sebenarnya. Kualitas produk ialah "comformance to specification". Keinginan konsumen harus dipenuhi agar menumbuhkan minat beli konsumen. Konsumen setelah menerima pelayanan, mereka akan membandingkan antara pelayanan yang diharapkan dan pelayanan yang mereka terima. Jika pelayanan yang diterima di bawah pelayanan yang diharapkan, konsumen tidak akan memiliki minat beli dan kehilangan kepercayaan terhadap penyedia produk tersebut. Sebaliknya jika pelayanan yang diharapkan sesuai maka konsumen akan memiliki minat beli. ${ }^{11}$

Responden memiliki asumsi yang mengatakan bahwa kualitas produk yang kurang baik akan menurunkan minat pembelian, tetapi kualitas produk yang baik akan meningkatkan minat pembelian.

\section{Hubungan Harga Dengan Minat Beli Konsumen Indocoverban di Jakarta Selatan}

Berdasarkan dari hasil bivariat, Hasil uji statistik diperoleh nilai $\mathrm{p}$ value $=0,000$ dengan $\mathrm{p}$ value $<0,05$ sehingga dapat diartikan bahwa ada hubungan yang bermakna antara harga dengan minat beli konsumen Jakarta Selatan tahun 2018. Hasil uji analisis menunjukan nilai Odds Ratio $(\mathrm{OR})=21,111$ artinya bahwa responden yang harga produk baik berpeluang 21,1 kali mengalami minat beli baik dibandingkan harga produk kurang baik.

Dengan penetapan harga yang baik dan sesuai dengan keinginan atau kehendak konsumen maka perilaku konsumen akan berubah (terpengaruh untuk melakukan pembelian). Sehingga berdasar pengertian di atas maka dapat disimpulkan bahwa harga sangat berpengaruh atas perilaku konsumen dalam melakukan minat pembelian pada suatu produk. ${ }^{4}$

Jika harga yang ditetapkan oleh perusahaan tidak sesuai dengan kualitas, keunggulan dan manfaat produk maupun fasilitas yang disediakan oleh perusahaan tersebut maka hal tersebut dapat menimbulkan citra yang kurang baik pada benak konsumen sehingga menurunkan minat beli pada konsumen. Sebaliknya, jika harga yang ditetapkan baik dan sesuai maka akan meningkatkan minat beli konsumen. $^{4}$

Hasil penelitian Oldy Ardhana di Semarang 2010 menunjukan bahwa terdapat hubungan antara harga terhadap minat beli konsumen dengan nilai t hitung lebih besar daripada nilai t tabel 4,879 > 1,661 dengan tingkat signifikan $0,000<0,05$. Hal ini disebabkan harga yang terjangkau namun disesuaikan dengan kualitas yang diterima pelanggan. ${ }^{21}$

Peneliti berasumsi bahwa harga memiliki pengaruh yang besar terhadap minat beli konsumen, maka harga yang ditawarkan harus sesuai dengan kualitas produk yang diterima oleh konsumen.

\section{Hubungan Citra Merek Dengan Minat Beli Konsumen Indocoverban di Jakarta Selatan}

Berdasarkan dari hasil bivariat, uji statistik diperoleh diperoleh nilai $\mathrm{p}$ value $=0,000$ dengan $\mathrm{p}$ value $<0,05$ sehingga dapat disimpulkan bahwa ada hubungan yang bermakna antara kesadaran merek dengan minat beli konsumen Indocoverban di Jakarta Selatan tahun 2018. Hasil uji analisis menunjukan nilai Odds Ratio $(\mathrm{OR})=17,250$ artinya bahwa responden yang citra merek produk baik berpeluang 17,2 kali mengalami minat beli baik dibandingkan citra merek produk kurang baik.

Konsumen mempercayai dan merasa aman pada suatu merek dengan segala resikonya, karena adanya harapan merek tersebut dapat memberikan hasil yang positif dan dapat diandalkan bagi konsumen, setelah diukur dengan ucapan pertama yang disebutkan konsumen, pengingatan kembali terhadap merek, bantuan ucapan ciri-ciri merek terhadap minat beli konsumen. ${ }^{10}$

Brand image atau citra merek menggambarkan kesanggupan seorang calon pembeli untuk 
mengenali, mengingat suatu brand sebagai bagian dari suatu kategori produk tertentu. Pada umumnya konsumen cenderung membeli produk dengan merek yang sudah dikenalnya atas dasar pertimbangan kenyamanan, keamanan dan lain-lain. Brand yang sudah dikenal menghindarkan konsumen dari risiko pemakaian dengan asumsi bahwa merek yang sudah dikenal dapat diandalkan. ${ }^{22}$

Hasil penelitian Jeria Tati Darwati 2014 menunjukan bahwa ada hubungan antara citra merek terhadap kepuasan konsumen dengan nilai t hitung lebih besar dari t tabel 6,182 >1,661 dengan tingkat signifikan $0,000<0,05$. Hal ini disebabkan citra merek konsumen terhadap suatu produk telah banyak diketahui melalui karakteristiknya. ${ }^{23}$

Peneliti berasumsi bahwa mengingat masih tingginya resiko minat beli konsumen terhadap citra merek produk Indocoverban, maka karakteristik dari produk yang ditawarkan harus sesuai dan bisa diingat oleh konsumen.

\section{Hubungan Promosi Dengan Minat Beli Konsumen Indocoverban di Jakarta Selatan}

Berdasarkan dari hasil bivariat, uji statistik diperoleh diperoleh nilai $\mathrm{p}$ value $=0,000$ dengan $\mathrm{p}$ value $<0,05$ sehingga dapat disimpulkan bahwa ada hubungan yang bermakna antara promosi dengan minat beli konsumen Indocoverban di Jakarta Selatan tahun 2018. Hasil uji analisis menunjukan nilai Odds Ratio $(\mathrm{OR})=19,475$ dapat di simpulkan bahwa responden yang promosi produk baik berpeluang 19,4 kali mengalami minat beli baik dibandingkan promosi produk kurang baik dalam usaha penjualan produk, teknik dan strategi pemasaran sangat berpengaruh pada jumlah penjualan produk yang akan dijual. Selain mempertahankan proses marketing, Promosi yang baik juga dapat meningkatkan minat beli pada konsumen.

Promosi yang dilakukan Indocoverban melalui social media dinilai paling efektif dan efisien di masa sekarang, karena jangkauan yang luas dan tidak memerlukan banyak biaya.

Hasil penelitian Anggit Yoebrilianti 2018 menunjukan bahwa ada hubungan antara promosi terhadap minat beli konsumen dengan nilai $t$ hitung lebih besar dari t tabel 20,553 > 1,654 dengan tingkat signifikan $0,000<0,05$. Hal ini berarti minat beli dipengaruhi oleh promosi penjualan. ${ }^{24}$

Peneliti berasumsi bahwa mengingat masih tingginya resiko minat beli konsumen terhadap promosi produk Indocoverban, maka Indocoverban dituntut untuk memberikan promosi yang menarik dan terbaru.

\section{Kesimpulan}

Kesimpulan dari penelitian ini yaitu Ada hubungan variabel kualitas produk terhadap minat beli konsumen produk Indocoverban di Jakarta Selatan. Ada hubungan variabel harga produk terhadap minat beli konsumen produk Indocoverban di Jakarta Selatan. Ada hubungan variabel citra merek produk terhadap minat beli konsumen produk Indocoverban di Jakarta Selatan. Ada hubungan variabel promosi produk terhadap minat beli konsumen produk Indocoverban di Jakarta Selatan.

\section{References}

1. www. tikom2sobang.wordpress.com diakses 5 Oktober 2018.

2. Ferdian S. Perilaku Konsumen: konsep dan Implikasi untuk Strategi dan Penelitian Pemasaran. Jakarta: Prenada Media; 2003.

3. www.paryadi.com/2018/01/16/jumlah- kendaraan-2018/ diakses 16 Okt 2018.

4. Kotler \& Amstrong. Prinsip-prinsip Pemasaran. Edisi 12. Jilid 1. Jakarta: Erlangga; 2008.

5. Oliver. Macroeconomic 4 Edition.Pearson Prentice Hall. New Jersey; 2006.

6. Kotler Philip and Gary Amstrong. Prinsip- prinsip Pemasaran. Edisi 12. Jilid 1. Jakarta: Erlangga; 2008.

7. Machfoedz. Pengantar Pemasaran Modern, edisi pertama, cetakan pertama. Yogyakarta: UPP AMP YKPN; 2005. 


\section{JIKOM \\ Jurnal Ilmiah Komunikasi}

Volume 12, No.03, November. 2020

8. Fatonah S \& Sigit R Analisis Faktor-Faktor Marketing MIX yang Mempengaruhi Konsumen Membeli Benih Jagung Hibrida Pioneer P21 di Kabupaten Bantul. Jurnal : STIE AUB; 2010.

9. Setiadi. Perilaku Konsumen: Konsep dan Implikasi untuk Strategi dan Penelitian Pemasaran. Jakarta: Prenada Media; 2003

10. Sangadji E.M dan Sopiah. Prilaku Konsumen: Pendekatan Praktis Disertai: Himpunan Jurnal Pendidikan. Yogyakarta : Penerbit Andi; 2013.

11. Tjiptono. Strategi Pemasaran. Jakarta: Andi; 2011.

12. Basu Swastha \& Irawan. Manajemen Pemsaran Modern. Surabaya: Liberty; 2004.

13. Hidayat. Metode penelitian Keperawatan dan Teknik Analisis Data. Jakarta: Salemba Medika; 2011.

14. Notoatmodjo S. Metodologi Penelitian Kesehatan. Jakarta: Rineka Cipta; 2010.

15. Richard West. Pengantar Teori Komunikasi: Analisis dan Aplikasi (Buku 2) (Edisi 3). Jakarta: Salemba Humanika; 2008.

16. Sugiyono. Metode Penelitian Kuantitatif Kualitatif dan R\&D. Bandung: Alfabeta; 2012.

17. Margono. Metodologi Penelitian Pendidikan. Jakarta: Rineka Cipta; 2004.

18. Arikunto. Prosedur Penelitian Suatu Pendekatan Praktek. Jakarta: Rineka Cipta; 2006.

19. Kriyantono. Public Relations \& Crisis Management: Pendekatan Critical Public Relations Etnografi Kritis \& Kualitatif. Jakarta: Kencana; 2012.

20. Saladin D. Intisari Pemasaran dan Unsur-unsur Pemasaran, Cetakan Ketiga. Bandung : Linda Karya; 2003.

21. Oldy Ardhana. Analisis Pengaruh Kualitas Pelayanan, Harga dan Lokasi Terhadap Kepuasan Pelanggan. (Studi Pada Bengkel Caesar Semarang). (Skripsi). Semarang: Universitas Diponegoro; 2010.

22. Aaker DA. Managing Brand Equity: Capitalizing on the value of a brandname. New York: Free Press; 2008.

23. Darwati JT. Pengaruh Citra Merek Terhadap Loyalitas Konsumen Dengan Kepuasan Konsumen Sebagai Mediasi Pada Produk Viva Kosmetik Di Kota Surabaya; 2014.

24. Anggit Y. Pengaruh Promosi Penjualan Terhadap Minat Beli Produk Fashion Dengan Gaya Hidup Sebagai Variabel Moderator (Survei Konsumen Pada Jejaring Sosial). Jurnal Manajemen Volume 8, Nomor 1, Juni 2018. 